\title{
Tradisi Slametan pada Masyarakat Jlatren, Jogotirto Berbah, Sleman, Yogyakarta
}

\author{
Naafi' Annisa, Amika Wardana \\ Program Studi Pendidikan Sosiologi, Fakultas IImu Sosial, Universitas Negeri Yogyakarta \\ Email : naafiannisa09@gmail.com
}

\begin{abstract}
Abstrak
Penelitian ini bertujuan mendeskripsikan jenis tradisi slametan, nilai budaya Islam dalam Slametan, dan tahapan pelaksanan Slametan. Penelitian ini menggunakan metode kualitatif deskriptif. Subjek penelitian berjumlah 4 orang, terdiri dari Pemuka Adat dan Agama atau disebut Mbah Kaum, sesepuh desa, dan masyarakat yang masih aktif menjalankan tradisi Slametan, pemilihan informan dengan teknik purposive sampling. Teknik pengumpulan data menggunakan observasi, wawancara, dan dokumentasi. Validitas data menggunakan teknik triangulasi. Teknik analisis data menggunakan analisis Milles dan Huberman. Hasil penelitian ini tradisi slametan terbagi dalam tiga jenis yaitu: Slametan pribadi, Slametan peringatan Hari Besar Agama Islam, dan Slametan yang berkaitan dengan tradisi Dusun. Nilai budaya Islam dalam tradisi Slametan adalah: (1) Perwujudan rasa syukur kepada Tuhan; (2) Memupuk kebiasaan bersedekah.; (3) Sarana penyampaian harapan kepada Tuhan; (4) Menghormati makhluk ghaib. Tahapan pelaksanaan Slametan dimulai dari penentuan tanggal lalu menunjuk perwakilan keluarga untuk menyampaikan undangan lisan Slametan awalnya akan dibuka oleh Rohis / Mbah Kaum serta akan disampaikan tujuan Slametan, pembacaan ayat Al-Qur'an dan doa, ditutup dengan pembagian ubarampe Slametan.
\end{abstract}

Kata Kunci : Tradisi Slametan, Agama Islam, Masyarakat.

\section{Abstract}

This study aims to describe the types of slametan traditions, Islamic cultural values in Slametan, and the stages of implementing Slametan. This research uses descriptive qualitative method. The research subjects consisted of 4 people, consisting of Customary and Religious Leaders or called Mbah Kaum, village elders, and people who were still actively carrying out the slametan tradition, selecting informants with purposive sampling techniques. Data collection techniques using observation, interviews, and documentation. Data validity uses triangulation techniques. Data analysis techniques using Milles and Huberman analysis. The results of this study are slametan traditions divided into three types, namely: personal slametan, slametan commemorating Islamic religious holidays, and slametan relating to the hamlet tradition. The values of Islamic culture in the slametan tradition are: (1) Embodiment of gratitude to God; (2) Cultivating the practice of charity; (3) Means of delivering hope to God; (4) Respect for supernatural beings. The stages of the implementation of the slametan start from determining the date and then appoint a family representative to deliver an oral invitation.

Keywords: Slametan Tradition, Islamic Religion, Society.

\section{Pendahuluan}

Islam berkembang dan melembaga di Nusantara melalui proses yang panjang. Masuknya Islam di Jawa membawa perubahan mendasar pada pola dan tatanan masyarakat, yang pada saat itu sebagian besar masih menganut agama Hindu (Rahman, 2012: 157). Islam muncul ditengah-tengah masyarakat melalui pertemuannya dengan 
budaya lokal, yang mengartikan bahwa Islam tampil tidak dengan muka Islam seluruhnya melainkan ditambah dengan polesan budaya yang ada (Rahman, 2012: 158-159). Agama yang tumbuh dan berkembang di Indonesia mau tidak mau harus berdialektika dengan budaya lokal yang kemudian mempunyai ciri khas dan keunikan tersendiri (Muqoyyidin, 2013: $3)$.

Berdasarkan sistem keagamaan dan kepercayaan yang mengacu pada penggolongan fenomena keagamaan Jawa oleh Clifford Geertz, menggunakan tiga tipologi yaitu abangan, santri, dan priyayi. Abangan, yang merepresentasikan penekanan pada aspek animistis dari sinkretisme Jawa yang serba melingkupi dan secara luas terkait dengan elemen petani; santri, yang mewakili penekan pada aspek Islam dari sinkretisme dan umumnya dihubungkan dengan elemen pedagang (juga kepada elemen tertentu dikalangan tani); serta priyayi, yang menekankan aspek Hindu dan terkait dengan elemen birokratik (Geertz, 2014: xxxii-xxxiii). Sebenarnya, dengan menggunakan ketiga tipologi tersebut, Geertz ingin menegaskan bahwa agama Islam di Jawa merupakan kumpulan ekspresi iman, doktrin, ritual dan lain-lain yang dipraktikkan masyarakat sesuai dengan tradisi lokal atau tempat dan waktu seiring dengan perkembangan dan penyebarannya (Muqoyyidin, 2013: 13).

Di Jawa, tradisi tertentu, mistisisme, Islam dan hinduisme, mengalami hibridisasi satu sama lain, masuk lebih jauh dari wacana ritual dan keagamaan; dan hakikat dari kombinasi yang lebih tinggi ini selanjutnya memengaruhi beberapa institusi dari ketiga unsur tradisi itu (Miharja, 2014: 204). Karena konteks Jawa yang melatari munculnya Islam di Jawa adalah animisme dan hinduisme, maka logis jika "warna dan citarasa" Islam yang berkembang di Jawa juga bernuansa animisme dan hinduisme (Muqoyyidin, 2013: 13). Salah satu adat istiadat, sebagai ritual keagamaan yang paling populer di dalam masyarakat Islam Jawa adalah "slametan", yaitu upacara ritual komunal yang telah mentradisi dikalangan masyarakat Islam Jawa yang dilaksanakan untuk peristiwa penting dalam kehidupan seseorang (Kholil, 2008: 196).

Ritual slametan juga menjadi salah satu media kelompok abangan dalam mengekspresikan wajah komitmen dan keagamaannya (Muqoyyidin, 2013: 14). Slametan yang menjadi tradisi luhur untuk mengiringi atau menandai berbagai perubahan dalam kehidupan seseorang adalah "doa" dan harapan sebagai ekpresi keberagamaan untuk memohon agar diberi "kelempangan" jalan, berkah rizqi, nasib baik yang itu semua disadari tidak dapat diraihnya tanpa "intervensi" 
Tuhan di dalamnya (Kholil, 2008: 188). Slametan yang dianggap sebagai ritual paling inti dalam masyarakat Jawa ini, dapat dijumpai dalam kehidupan masyarakat di Dusun Jlatren, Jogotirto, Berbah, Sleman, Yogyakarta. Penelitian ini bertujuan mendeskripsikan jenis-jenis tradisi slametan, nilai budaya Islam dalam tradisi slametan, dan tahapan pelaksanaan tradisi slametan.

\section{Metode}

Penelitian ini menggunakan metode penelitian kualitatif dengan pendekatan deskriptif. Lokasi penelitian ini adalah di Dusun Jlatren, Desa Jogotirto, Kecamatan Berbah, Kabupaten Sleman, Yogyakarta. Lokasi dipilih karena di dusun ini masih menerapkan tradisi slametan secara rutin dan masih sangat lengkap, baik meliputi slametan pribadi, slametan peringatan hari besar Islam, dan slametan yang berkaitan tradisi. Subyek penelitian ini diambil dengan menggunakan teknik purposive sampling yaitu: masyarakat Dusun Jlatren khususnya yang sudah pernah mengadakan acara slametan, sesepuh desa, dan tokoh pemuka adat/agama yang cukup disegani di dusun ini yang biasanya mengarahkan jalannya setiap upacara adat yang biasa disebut dengan Mbah Kaum. Teknik pengumpulan data menggunakan observasi, wawancara, dan dokumentasi kemudian untuk validitas data menggunakan teknik triangulasi. Teknik analisis data dalam penelitian ini menggunakan analisis Milles dan Huberman.

\section{Hasil dan Pembahasan}

Slametan di Dusun Jlatren terbagi menjadi tiga jenis yang didasarkan pada slametan yang dilaksanakan secara pribadi, slametan peringatan hari besar Agama Islam, dan slametan yang berkaitan dengan tradisi. Sedangkan jika dilihat dari skala besar-kecilnya pelaksanaan tradisi slametan ini terdapat dua jenis yaitu: slametan kecil dan slametan besar. Slametan kecil merupakan slametan yang diselenggarakan dengan hanya mengundang tetangga sekitar rumah pemilik hajat saja sehingga cakupannya relatif lebih kecil. Adapun beberapa jenis slametan kecil adalah: brokohan dan sepasaran. Sedangkan slametan besar merupakan slametan yang diselenggarakan dengan mengundang seluruh warga dusun, sehingga cakupannya relatif lebih besar. Adapun beberapa jenis slametan besar adalah keseluruhan jenis slametan di Jlatren kecuali slametan brokohan dan sepasaran.

Slametan pribadi secara umum dilaksanakan dengan tujuan sebagai wujud rasa syukur atas limpahan nikmat yang diberikan Tuhan kepada kehidupan seseorang sekaligus menandai beberapa peristiwa atau peralihan waktu yang dianggap penting dalam kepercayaan masyarakat Jawa, selain itu untuk 
mendoakan agar segala pengharapan yang baik dapat terwujud. Slametan pribadi ini meliputi beberapa krisis kehidupan antara lain: kehamilan, kelahiran, perkawinan, dan kematian. Dalam slametan kehamilan terbagi dalam dua jenis yaitu slametan 4 bulan kehamilan dan 7 bulan kehamilan (mitoni). Slametan kelahiran yang meliputi slametan brokohan, sepasaran, salapanan. Lalu slametan perkawinan (walimatul ursy) hanya terdapat satu jenis saja. Sedangkan slametan kematian terbagi ke dalam beberapa jenis yaitu: slametan surtanah, 7 harinan (pitung dinanan), 40 harian (patang puluh dinanan), 100 (nyatus), mendhak pisan, mendhak pindho, dan 1000 harian (nyewu).

Slametan pertama dalam slametan pribadi yaitu slametan kehamilan 4 bulanan dan 7 bulanan kandungan (mitoni). Slametan 4 bulanan dilakukan untuk mendoakan, memperingati, dan mensyukuri bahwa Tuhan telah meniupkan ruh ke dalam janin yang dikandung agar selalu diberikan keselamatan hingga persalinan, konsep kesalamatan dalam waktu persalinan tersebut sesuai dengan falsafah Jawa (wilujeng, santosa, jatmika, rahayu). Dalam hal ini keluarga memohon doa agar janin senantiasa dapat lahir dengan selamat, sehat, dan sempurna.

Sedangkan slametan 7 bulanan bertujuan supaya saat proses persalinan nanti bagi ibu dan bayinya diberikan keselamatan, biasanya mitoni ini dilaksanakan bagi kehamilan pertama seorang ibu. Mitoni berasal dari kata "pitu" yang dalam Bahasa Indonesia berarti tujuh, yang memiliki arti pitulungan atau pertolongan. Adapun ubarampe secara umum dalam slametan mitoni / 7 bulanan, adalah nasi dan lauk pauk. Adapula ubarampe khusus yaitu berupa ketan kuning, janur kuning (daun kalapa muda), dan pisang mas. Pengemasan ubarampe khusus ini adalah ketan kuning yang telah matang dimasukkan ke dalam wadah kecil yang diberi potongan janur kuning dan diatasnya ditaruh pisang mas. Tujuan pemberian ubarampe khusus tersebut adalah mengandung harapan agar jika melahirkan anak perempuan menjadi anak yang cantik, jika seorang laki-laki maka menjadi anak yang tampan. Ketampanan dan kecantikan ini dalam kepercayaan masyarakat Jawa dilambangkan dengan warna dari ketan kuning, janur kuning, dan pisang mas.

Slametan kelahiran (brokohan), bertujuan mendoakan bayi sekaligus sebagai wujud rasa syukur atas kelahirannya juga keselamatan ibu dan bayinya, yang dalam Bahasa Jawa disebut "menang perang sabil". Pelaksanaannya mengundang ibu-ibu yang berada di lingkungan sekitar rumah. Brokohan merupakan upacara syukuran atas kelahiran bayi, dengan harapan agar bayi tersebut mendapatkan brokoh atau berkah yang artinya kebaikan yang terusmenerus dan diberi keselamatan oleh 
Tuhan. Disini keluarga menyiapkan ubarampe slametan yang berupa tumpeng berisi nasi, sayur, dan lauk pauk yang kemudian nanti akan di bagi-bagi menjadi beberapa bungkus atau pincuk dengan pembungkus daun pisang atau kertas nasi untuk dibagikan kepada ibuibu yang datang.

Kemudian slametan sepasaran, diadakan pada waktu bayi berumur 5 hari, yang biasanya bertepatan dengan lepasnya tali pusar bayi (puput puser), karena inilah terkadang selapanan disebut juga puputan. Sepasaran biasanya mengundang anak-anak kecil di sekitaran rumah warga yang mempunyai hajat. Ubarampe yang disiapkan adalah nasi, sayur gudangan, lauk, buah, dan jajanan pasar yang ditaruh dalam wadah yang terbuat dari kertas (cekethong). Adapun ubarampe khusus dalam slametan sepasaran ini adalah 5 macam jenang, dalam kepercayaan masyarakat Jawa kelima jenang tersebut mengandung makna berbeda-beda.

Lalu terdapat slametan selapanan yang biasanya dilaksanakan bersamaan dengan Aqiqohan. Slametan ini yang diundang relatif lebih banyak daripada slametan brokohan dan selapanan. Selapanan ini merupakan peringatan hari nepton si bayi, dan menurut kepercayaan, hari nepton akan menjadi dasar dalam peringatan dalam peristiwaperistiwa penting dalam perjalanan kehidupannya kelak (Hartika, 2016: 1819). Disini keluarga akan membagikan nasi berkat yang berisi nasi, nasi uduk atau nasi gurih dan suwiran ayam ingkung, sayur, lauk-pauk termasuk daging olahan dari hewan yang sembelih untuk aqiqohan, jajanan pasar, dan buah yang 'dikemas dalam satu wadah plastik besar yang biasa disebut dengan baskom. Selapanan ini biasanya dilaksanakan pada hari ke tiga puluh lima setelah kelahiran bayi. Adapun ubarampe khusus semacam tumpeng yang berisi nasi yang dibentuk kerucut, dibawahnya dikelilingi oleh sayur gudangan, telur ayam kampung rebus, jajanan pasar, kemudian diatas tumpeng nasi diberi semacam lidi yang telah diberi tusukan cabai merah besar dan bawang merah yang dipasang dalam posisi vertikal dan horizontal.

Tumpeng nasi yang dikelilingi aneka sayur dan lauk pauk mengandung filosofi seperti gunung yang dikelilingi tanah dan tanamanan subur disekelilingnya. Tumpeng ini setelah didoakan akan ditempatkan di sekitaran tempat tidur bayi, dengan tujuan agar bayi dijauhkan dari segala gangguan yang berasal dari makhluk halus sehingga mampu terhindar dari segala mara bahaya. Tumpeng dalam kepercayaan masyarakat Jawa merupakan ungkapan dari "metuo dalan ingkang lempeng" yang berarti manusia dalam menjalani hidup harus berada di jalan yang benar, jauh dari segala kesesatan dan kejahatan (Setyowati \& Hanif, 2014: 8).

Slametan perkawinan bertujuan 
untuk mendoakan calon pengantin agar dapat menempuh rumah tangga yang sesuai dengan syariat yang telah diajarkan. Dalam acara ini keluarga telah menyiapkan nasi lengkap dengan lauk pauk yang ditata dalam suatu wadah untuk dibagikan kepada para kepala keluarga yang hadir dalam acara tersebut. Dalam slametan ini terdapat ubarampe khusus yang biasanya disebut sajen yang ditempatkan dalam satu wadah yang disebut sarang. Sarang terbuat dari anyaman daun kelapa tua. Sarang ini diisi oleh sebagian dari makanan yang dibuat selama hajatan berlangsung yaitu nasi, sayur dan jajanan pasar yang dibuat dalam hajatan (lemper, tape ketan, emping, dan jenang). Penempatan sajen ini biasanya di tujuh titik yaitu: empat pojok-pojok desa sesuai arah mata angin, sumur di rumah warga yang mempunyai hajat, di dalam rumah yang berfungsi sebagai pusat penyajian konsumsi hajatan, dan di dapur rumah warga yang mempunyai hajat.

Selanjutnya dalam slametan kematian terbagi dalam beberapa jenis yaitu: surtanah, 7 hari (pitung dinanan), 40 hari (patang puluhan), 100 hari (nyatus), 1 tahunan (mendak sepisan), 2 tahunan (mendak pindho), dan 1000 hari (nyewu). Keseluruhan slametan kematian yang diperingati setelah slametan surtanah yakni dari slametan pitung dinanan hingga slametan nyewu terdapat suatu kesamaan yakni terdapat ubarampe khusus yang perlu dipersiapkan. Ubarampe tersebut adalah tiga jenis makanan yaitu ketan, kolak, dan kue apem. Kesatuan makna dari filosofis ubarampe ketan, kolak, dan kue apem ini adalah bahwa orang yang sudah meninggal akan otomatis terputus dari segala hal yang berkaitan dengan duniawi, ditandai dengan sudah tidak mampu lagi untuk berbicara, maka keluarga akan mewakili orang yang meninggal tersebut untuk memintakan maaf atas segala kesalahannya kepada orang-orang yang masih hidup.

Lalu ubarampe wajib yang harus selalu disiapkan dalam setiap slametan kematian disamping ubarampe khusus tersebut, ada nasi gurih dan suwiran ingkung. Sedangkan ubarampe umumnya sedikit berbeda dari slametan pada umumnya yang biasanya menyediakan nasi, sayur, dan lauk-pauk digantikan dengan bahan makanan mentah seperti beras, gula pasir, teh, telur, dan mie instan. Dalam setiap slametan kematian pemilik hajat wajib menyediakan ayam jago untuk dijadikan ingkung.

Rangkaian slametan kematian dimulai dari slametan surtanah berasal dari kata ngesur tanah yang berarti mendesak. Maksudnya orang yang meninggal meminta maaf kepada ahli kubur yang tanahnya di desak (disur). Tujuannya adalah supaya bisa hidup tenang di alam kubur dan tidak mempunyai kesalahan kepada ahli kubur yang berdekatan. Slametan ini 
dilaksanakan pada hari kematian seseorang, tepatnya setelah jenazah dikebumikan. Kemudian slametan pitung dinanan (7 hari), dilaksanakan pada hari ke 7 setelah meninggal dunia. Tujuannya, agar orang yang meninggal diberikan keselamatan dan tenang di alam kubur. Slametan ini sebagai syukuran atas selesainya tahlil, maka warga yang hadir akan diberikan sedekah berupa nasi dan lauk pauknya.

Slametan patang puluhan (40 hari), dilaksanakan pada hari ke 40 setelah meninggal dunia. Slametan ini bertujuan memberi penghormatan kepada roh orang yang meninggal yang sudah mulai keluar dari pekarangan dan akan menuju alam kubur. Lalu slametan nyatus (100 hari), dilaksanakan pada hari ke seratus setelah orang tersebut meninggal dunia. Setelah slametan nyatus ini akan diadakan Slametan mendhak pisan (1 tahun), slametan ini dilaksanakan setahun setelah orang tersebut meninggal dunia. Selanjutnya ada slametan mendhak pindho (2 tahun), slametan ini dilaksanakan dua tahun setelah orang tersebut meninggal dunia.

Slametan nyewu (1000 hari), dilaksanakan pada hari ke 1000 (2 tahun 10 bulan) setelah meninggal dunia, yang mana slametan ini merupakan puncak dari rangkaian tradisi slametan kematian dalam masyarakat Jawa. Terdapat ubarampe khusus yang khas ditemukan pada saat slametan nyewu, yaitu pemakaian ubarampe yang berupa penyembelihan kambing. Kambing dalam kepercayaan masyarakat Jawa dimaksudkan sebagai kendaraan orang yang meninggal tersebut di alam kubur.

Selanjutnya terdapat jenis slametan yang kedua yakni slametan peringatan hari besar Agama Islam. Slametan peringatan hari besar Agama Islam ini dilaksanakan dalam rangka memuliakan bulan ataupun hari-hari tertentu yang bertalian dengan agama Islam misalnya bulan Maulud, Muharram, Ramadhan, dan Idul Fitri.

Dalam slametan peringatan hari besar agama Islam ini tidak terdapat ubarampe khusus, hanya perlu menyiapkan ubarampe umum dalam slametan yang berupa nasi dan lauk pauk yang dimaksudkan hanya untuk bersedekah. Dimulai dari slametan 10 Muharram ini dilaksanakan pada malam ke 10 bulan Muharram, atau biasa disebut ngasura. Tujuan diadakan slametan ini secara umum adalah untuk memperingati peristiwa-peristiwa yang dialami oleh para Nabi dan Rasul. Lalu slametan Maulidan ini dilaksanakan pada malam ke 12 bulan Rabi'ul Awal (Mulud), atau biasa disebut Muludan. Tujuan diadakan slametan ini adalah untuk memperingati hari lahir Nabi Muhammad SAW.

Selanjutnya slametan nisfu sya'ban ini dilaksanakan pada malam tanggal 15 bulan Sya'ban / Ruah. Tujuan diadakaannya slametan ini adalah untuk memperingati hari dimana semua buku catatan amalan perbuatan manusia di 
dunia selama setahun yang akan diserahkan kepada Tuhan, selain itu terdapat pengharapan bahwa dengan adanya slametan ini semua manusia akan memiliki catatan amalan yang baik. Lalu slametan Lalilatul Qodar, ini dilaksanakan pada malam 21 bulan Ramadhan. Tujuan diadakaannya slametan ini adalah untuk mendapatkan keberkahan dari malam Lailatul Qodar. Slametan 1 Syawal, ini dilaksanakan pada malam hari Raya Idul Fitri. Slametan ini sebagai wujud rasa syukur telah berhasil menjalankan puasa selama 30 hari tanpa ada halangan suatu apapun, dengan tujuan agar amal ibadah selama satu bulan tersebut diterima oleh Tuhan.

Selanjutnya jenis slametan yang ketiga yakni slametan yang berkaitan dengan tradisi, yang terdiri dari slametan merti desa atau rasulan dan nyadran. Slametan merti desa atau rasulan, merupakan tasyakuran yang diadakan oleh seluruh warga atas keberhasilan panen rendhengan/ di musim penghujan/masa tanam pertama. Tujuan diadakan slametan ini adalah sebagai rasa syukur atas hasil bumi yang baik dan melimpah dalam satu tahun, selain itu juga diharapkan agar tanaman yang akan ditanam di musim tanam selanjutnya akan berhasil. Pada slametan ini warga akan membawa ubarampe yang hampir sama seperti dengan pada umumnya yaitu nasi dan lauk pauk, khusus di slametan rasulan dan nyadran ini ditambahkan ubarampe berupa aneka jajanan pasar dan buah-buahan.

Slametan nyadran ini dilaksanakan pada tanggal 25 bulan Sya'ban/Ruah. Slametan ini merupakan kumpul bersama untuk membaca tahlil bagi para leluhur semoga diampuni segala dosa-dosanya dan diterima segala amal baiknya. Pada slametan ini warga akan membawa ubarampe yang hampir sama seperti dengan pada umumnya yaitu nasi dan lauk pauk, khusus di slametan rasulan dan nyadran ini ditambahkan ubarampe berupa aneka jajanan pasar dan buahbuahan. Ubarampe nasi bermakna simbolis sebagai hasil panen dari sawah. Sedangkan ubarampe sayur, lauk-pauk, dan buah-buahan bermakna simbolis sebagai hasil panen dari kebun. Lalu ubarampe jajanan pasar bermakna simbolis sebagai hasil rezeki diluar dari sawah dan kebun.

Selanjutnya mengenai nilai dan tujuan slametan, berdasarkan hasil wawancara terdapat empat nilai dan tujuan yaitu: perwujudan rasa syukur kepada Tuhan, memupuk kebiasaan bersedekah, sarana penyampaian harapan kepada Tuhan, dan menghormati makhluk ghaib. Pertama, perwujudan rasa syukur kepada Tuhan. Jika dilihat bahwa adanya unsur agama Islam terlihat jelas dalam slametan rasulan, dijadikan alasan utama diadakannya slametan tersebut adalah rasa syukur kepada Allah SWT. Manifestasi rasa syukur tersebut kemudian diwujudkan dengan 
mengadakan slametan rasulan yang diadakan seusai masa panen rendhengan tiba. Yang mana dalam cara tersebut warga membawa aneka makanan dan buah-buahan sebagai simbolisasi keberhasilan panen di ladang maupun sawah yang harus disyukuri. Kedua, memupuk kebiasaan bersedekah. Islam telah menganjurkan agar umatnya bersedekah, maka janji Allah bagi umatnya yang bersedekah adalah akan melipat gandakan kenikmatan baginya. Bertambahnya kenikmatan disini dijadikan motivasi agar manusia senantiasa bersyukur. Dalam konteks slametan, unsur bersedekah ini diimplementasikan oleh masyarakat dengan memberikan ubarampe slametan yang berupa jajanan pasar yang bermaksud sebagai sedekah untuk menggapai keselamatan hidup.

Ketiga, sarana penyampaian harapan kepada Tuhan. Dalam konteks slametan di Dusun Jlatren terdapat aktualisasi nilai-nilai budaya Islam yang terlihat pada pembacaan doa-doa, shalawat Nabi, maupun pembacaan ayatayat Al-Qur'an selama proses slametan yang kesemuanya itu mengandung makna sebagai sarana penyampaian harapan kepada Tuhan untuk mendapatkan keselamatan, kemakmuran, dan dijauhkan dari hal-hal yang tidak diinginkan. Keempat, menghormati makhluk ghaib. Dalam konteks slametan, masyarakat mengimplementasikan wujud penghormatannya kepada makhluk ghaib tersebut dengan meletakkan ubarampe slametan tertentu dalam tempat-tempat tertentu pula. Sebagai contoh, seperti dalam slametan pernikahan terdapat ubarampe berupa sajen kemudian dimasukkan ke dalam wadah yang disebut sarang. Penempatan sajen ini biasanya di tujuh titik yaitu: empat pojokpojok desa sesuai arah mata angin.

Selanjutnya pelaksanaan tradisi slametan di Dusun Jlatren dilakukan dalam beberapa tahapan yang secara umum hampir sama antara satu jenis slametan dengan slametan lainnya. Adapun bila terdapat perbedaan hanya terletak pada bagian penyediaan ubarampe khusus dan penambahan doadoa khusus sesuai dengan jenis slametan yang berlangsung. Pertama dilakukan tahap persiapan terlebih dahulu yaitu dengan menentukan tanggal pelaksanaan slametan sesuai dengan penanggalan jawa yang telah disepakati. Kemudian keluarga akan menunjuk salah seorang perwakilan dari keluarga untuk datang (sowan) ke rumah Rohis atau Mbah Kaum dan rumah-rumah warga yang akan diundang ke acara slametan dengan maksud untuk mengundangnya.

Sedangkan untuk waktu pelaksanaan acara slametan dilaksanakan setelah shalat Maghrib atau setelah sholat Isya. Kemudian memasuki acara inti slametannya, dimulai dengan pembukaan acara oleh Rohis atau Mbah Kaum yang kemudian akan menjelaskan 
maksud dan tujuan acara slametan yang dilaksanakan tersebut. Selanjutnya Rohis atau Mbah Kaum akan memimpin pembacaan ayat-ayat Al-Qur'an seperti surat-surat pendek, lalu akan ditutup dengan pembacaan doa-doa yang juga akan disesuaikan dengan jenis slametan yang berlangsung.

Dalam slametan pribadi, dibagian akhir acara akan dijamu dengan makanan dan minuman, kemudian ketika akan pulang dibagikan ubarampe umum slametan. Ubarampe umum slametan ini biasanya sebagai wujud sedekah yang bisa berupa makanan matang yaitu nasi, sayur, lauk-pauk, jajanan pasar, buah, dan ditambahkan ubarampe-ubarampe khusus slametan. Namun dalam beberapa jenis slametan seperti rangkaian slametan kematian, bahan makanan matang tersebut diganti dengan bahan makanan mentah seperti mie instan, beras, telur, gula, teh, jajanan pasar, dan ubarampe khusus slametan kematian.

Sedangkan dalam slametan peringatan Hari Besar Agama Islam dan slametan yang berkaitan dengan integrasi dusun, tahapan pelaksanaannya hampir sama dengan slametan pribadi. Dimulai dengan pembukaan acara oleh Rohis atau Mbah Kaum, kemudian akan diberikan penjelasan mengenai pemaknaan dan tujuan diadakannya slametan tersebut. Lalu dilanjutkan dengan pembacaan doa oleh Rohis atau Mbah Kaum, kemudian di akhir acara dipersilahkan untuk menikmati ubarampe yang telah dibawa oleh setiap keluarga yang menghadiri acara tersebut.

Terdapat temuan menarik dalam penelitian ini yaitu terdapat titik temu ajaran Agama Islam dan kebudayaan Jawa dalam ubarampe tradisi slametan. Pertama, yaitu tumpeng. Dalam kepercayaan masyarakat Jawa tumpeng merupakan ungkapan dari "metuo dalan ingkang lempeng" yang berarti manusia dalam menjalani hidup harus berada di jalan yang benar, jauh dari segala kesesatan dan kejahatan (Setyowati \& Hanif: 8). Nasi tumpeng yang dibentuk kerucut ditempatkan di tengah-tengah dengan berbagai macam lauk-pauk yang disusun disekelilingnya. Penempatan seperti ini mengandung makna filosofis dan simbolis dimana nasi sebagai simbol sebuah gunung dan lauk-pauk di sekelilingnya sebagai simbol tanah atau tanaman yang tumbuh subur. Kerucut nasi yang menjulang tinggi menjulang tinggi melambangkan keagungan Tuhan Yang Maha Pencipta alam beserta isinya, sedangkan aneka lauk-pauk dan sayuran merupakan simbol dari isi alam ini (Setyowati \& Hanif, 2014: 9). Maka dengan adanya tumpeng tersebut diharapkan manusia selalu mengingat keagungan dan kekuasaan Allah SWT.

Kedua, yaitu ayam ingkung. Ingkung merupakan ubarampe yang berupa ayam kampung utuh yang dimasak dengan diberi bumbu. Ingkung 
ini menurut kepercayaan Jawa mengandung makna sebagai wujud persembahan untuk para leluhur yang telah memberikan keselamatan dan kemakmuran. Ayam ingkung ini sendiri merupakan ayam utuh yang dimasak dengan keadaan kaki dan kepalanya diikat menyerupai seperti orang yang sedang bersujud, hal tersebut bermakna agar manusia senantiasa bersujud dan berzikir kepada Allah SWT sesuai dengan ajaran Nabi Muhammad SAW.

Ketiga, yaitu jajanan pasar. Jajanan pasar dalam kepercayaan masyarakat Jawa bermakna sebagai sedekah untuk menggapai keselamatan hidup dan terhindar dari segala gangguan makhluk ghaib. Jajanan pasar adalah lambang dari sesrawungan (hubungan kemanusiaan, silahturahmi) dan lambang kemakmuran (Setyowati \& Hanif, 2014: 10). Dalam hal ini jajanan pasar mengandung makna mendalam agar manusia senantiasa menjalin hubungan silaturahmi antar sesama manusia sesuai apa yang diajarkan dalam agama Islam yang disebut dengan haabluminannas. Keempat, yaitu kue apem. Kue apem ini mengadopsi dari kata dalam Bahasa Arab "Afuwun" yang berarti memohon ampun, maksudnya orang yang sudah meninggal ini meminta ampun atas segala kesalahan dan dosa yang pernah dia perbuat selama hidupnya.

Kelima, yaitu ketan. Ketan mengadopsi dari kata dalam Bahasa Arab "Qhotoa" yang berarti telah putus, maksudnya orang yang telah meninggal akan putus dari segala hal yang berkaitan dengan dunia. Keenam, yaitu kolak. Kolak mengadopsi dari kata dalam Bahasa Arab "Qolaa" yang berarti ucapan, maksudnya bahwa orang yang sudah meninggal tidak bisa berbicara lagi. Ketujuh, yaitu Nasi uduk (wuduk) atau gurih. Nasi gurih dalam kepercayaan masyarakat Jawa dimaknai sebagai upaya meluhurkan Nabi Muhammad SAW yang telah memberikan keselamatan kepada umat manusia.

Dalam perspektif fenomenologi tentang tradisi slametan Dusun Jlatren yakni memandang perilaku dan tindakan manusia sebagai suatu yang bermakna, karena manusia memberikan makna pada perilaku dan tindakan tersebut. Manusia juga merupakan makhluk yang mempunyai "tujuan" dalam mewujudkan tindakannya. Adanya tujuan dan pengetahuan di balik perilaku dan tindakan inilah yang melahirkan "makna" terhadap perilaku dan tindakan tersebut, serta terhadap "objek" nya. Sedangkan agama dalam sudut pandang fenomenologi adalah suatu kesadaran, sebagai suatu kesadaran agama dapat bersifat individual maupun kolektif. Sebagai sebuah kesadaran individual, agama menekankan kesadarankesadaran, pengetahuan-pengetahuan, pandangan-pandangan individual, bersifat khas, kemudian mendorong munculnya perilaku-perilaku individual yang khas pula. 
Berkaitan dengan perilaku individual yang khas dalam beragama inilah salah satunya dapat tercermin dari perilaku masyarakat di Dusun Jlatren dalam menjalankan tradisi slametan yang masih digelar secara rutin. Hal ini tentu dianggap sebagai suatu perilaku yang bersifat khas karena pelaksanaan tradisi slametan yang biasanya dilakukan oleh masyarakat Jawa pada umumnya juga dilaksanakan oleh masyarakat yang beragama muslim, meskipun dalam beberapa jenis slametan tertentu seperti slametan kematian tidak terdapat tuntunan yang menjelaskan akan hal tersebut namun lebih mengarah pada kepercayaan atau ajaran agama lainnya atau dalam kata lain telah mengalami proses sinkretisasi. Pelaksanaan tradisi slametan tersebut juga dipandang memiliki makna dan tujuan yang khas pula sesuai dengan jenisnya masingmasing entah itu slametan pribadi, peringatan Hari Besar Islam, dan slametan yang berkaitan dengan tradisi.

Adapun makna khusus sangat terlihat dalam beberapa ubarampe yang khas dalam setiap jenis tradisi slametan diantaranya: ketan kolak dan kue apem, dalam slametan kematian, tumpeng nasi selapanan yang menggunakan tusukan dari cabe dan bawang merah yang dibentuk khas, 5 macam jenang dalam slametan sepasaran, ketan janur dan pisang mas dalam slametan mitoni, hasil bumi (nasi, lauk, sayur) dan hasil kebun (buah-buahan) serta jajanan pasar dalam slametan rasulan, serta sarang dalam slametan perkawinan. Makna khusus yang tercermin dalam tradisi slametan juga terlihat dalam pemilihan tanggal pada jenis-jenis slametan tertentu seperti slametan kematian (hari-1, hari ke-7, hari ke-40, hari ke-100, hari ke-1 tahun, hari ke-2 tahun, dan hari ke-1000) dan pada slametan peringatan Hari Besar Islam (tanggal 10 Muharram, 12 Maulud, 15 Sya'ban, 21 Ramadhan, dan 1 Syawal).

Masyarakat memberikan makna bagi tradisi slametan dan tetap menjaga agar tradisi tersebut tidak pernah punah dengan cara terus menerus melaksanakan tradisi tersebut ketika bertepatan dengan waktu-waktu dalam krisis kehidupan seperti kehamilan, kelahiran, perkawinan, kematian, harihari besar Agama Islam, syukuran hasil panen, maupun tradisi yang dilaksanakan sebagai agenda rutin dusun pasti akan diadakan perayaan sesuai dengan prosesi tradisi yang sejak dahulu berlangsung.

\section{Simpulan}

Slametan yang terdapat di Dusun Jlatren terbagi menjadi 3 jenis, pengelompokan ini di dasarkan pada slametan yang dilaksanakan secara pribadi, slametan peringatan hari besar Agama Islam, dan slametan yang berkaitan dengan tradisi. Terdapat nilai dan tujuan slametan diantaranya: perwujudan rasa syukur kepada Tuhan, memupuk kebiasaan bersedekah, sarana 
penyampaian harapan kepada Tuhan, dan menghormati makhluk ghaib. Slametan yang dijalankan di dusun ini terlihat jelas berbeda dengan tradisi slametan yang pada umunya dilakukan oleh masyarakat perdesaan yakni yang sangat kental nuasa Hindu dan Buddha, namun sangat jelas terlihat dominannya nilai-nilai budaya Islam di dalamnya.

$\begin{array}{lcr}\text { Dalam } & \text { konteks } & \text { kajian } \\ \text { fenomenologi } & \text { agama, perilaku } \\ \text { masyarakat dalam melaksanakan }\end{array}$ slametan ini termasuk perilaku individual yang khas karena memiliki makna dan tujun yang khas pula sesuai dengan jenisnya masing-masing entah itu slametan pribadi, peringatan Hari besar Islam, dan slametan yang berkaitan dengan tradisi. Masyarakat memberikan makna bagi tradisi slametan dan tetap menjaga agar tradisi tersebut tidak pernah punah dengan cara terus menerus melaksanakan tradisi tersebut ketika bertepatan dengan waktu-waktu dalam krisis kehidupan seperti kehamilan, kelahiran, perkawinan, kematian, hari-hari besar Agama Islam, syukuran hasil panen, maupun tradisi yang dilaksanakan sebagai agenda rutin dusun pasti akan diadakan perayaan sesuai dengan prosesi tradisi yang sejak dahulu berlangsung.

\section{Ucapan Terima Kasih}

Terima kasih kepada semua pihak yang telah mendukung penulisan artike ini. Kami juga mengucapkan terima kasih kepada redaksi Jurnal Dimensia yang telah menerbitkan tulisan ini.

\section{Daftar Pustaka}

Geertz, C. 2014. Agama Jawa. Depok: Komunitas Bambu.

Kholil, A. 2008, September-Desember). Agama dan Ritual Slametan. Jurnal El-Harakah, 10.

Mulder, N. 2001. Mistisme Jawa : Ideologi di Indonesia. Yogyakarta: LKIS Pelangi Aksara.

Muqoyyidin, A. W. 2013. Dialektika Islam dan Budaya Lokal Jawa. Ibda : Jurnal Kebudayaan islam.

Rosyidi, A. W. 2012. Doa Dalam Tradisi Islam Jawa. el Harakah, 14.

Sari, D. A. 2017. Slametan Kematian Di Desa Jaweng Kabupaten Boyolali. Haluan Sastra Budaya.

Setyowati, A., \& Hanif, M. 2014. Peran Perempuan Dalam Tradisi Upacara Bersih Desa (Studi Kasus Di Desa Kiringan Kecamatan Takeran Kabupaten Magetan). Jurnal Sejarah dan Pembelajarannya 4, 01.

Sugiono. 2017. Metode Penelitian Kualitatif . Bandung: Alfabeta.

Sutiyono. 2010. Benturan Budaya Islam : Puritan \& Sinkretis. Jakarta: Kompas.

Turner, B. S. 2013. Sosiologi Agama. (Daryatno, Trans.) Yogyakarta: Pustaka Pelajar. 